\title{
Seasonal distribution of the littoral interstitial meiofauna in the northern Red Sea, Egypt
}

\author{
Mahmmoud H. Hanafy; Diaa Eddien A. Mohammed and \\ Ashraf I. Ahmed
Marine Science Department, Faculty of Science, Suez Canal University, Ismailia, Egypt

\begin{abstract}
$\mathrm{M}$ eiofaunal composition, distribution and seasonal abundance in the northern Egyptian Red Sea were studied during the period from spring 2006 to winter 2007. Significant seasonal variation in the density was recorded $(P<0.001)$ and ranged between 100 and 130 organisms $/ 10 \mathrm{~cm}^{2}$. The meiofaunal assemblage in the area of study was well diversified including 141 species. The principal taxonomic groups were free living Nematoda $(68 \%)$ followed by Harpacticoida (12\%), Polychaeta (10\%) and Ostracoda (4\%) in term of their densities. The exposure to wave actions and the sediment characteristics were the most important factors for structuring the meiofaunal community.
\end{abstract}

Key words: Meiofauna, seasonal abundance, Red Sea, Egypt.

\section{INTRODUCTION}

The Red Sea region has diverse economic activities; these activities include offshore oil exploration, phosphate mining, and fishing on a limited scale. Starting from the early 1990s, the Red Sea region has been targeted for massive tourism development in Egypt (Shaalan, 2005). In 2000, the existing number of rooms was 10,549 . The target for 2012 is to achieve 140,000 rooms primarily by constructing new resorts and secondly by expanding the existing ones. The majority of the resorts were built along a coastal stretch of about 300 $\mathrm{km}$ with about $50-200 \mathrm{~m}$ coastal setback depending on the shoreline conditions (JICA, 1999). All of these activities might alter the benthic environment in general and the meiobenthic communities in particular.

Sandy beaches are not just piles of sand; they support a range of underappreciated biodiversity. A single beach can harbour several hundred of small forms of invertebrates (i.e. meiofauna) (Armonies and Reise, 2000). Meiofauna plays an important role as a trophic link between bacteria and larger fauna (Hicks 1984), in addition, they are also known as sensitive indicators of environmental disturbance and have great potential as pollution indicators (Soule 1988; Coull, 1990; Montagna \& Kalke 1992; Shaw \& Jenkins, 1992).

The quantitative distributions of the meiobenthos in the Egyptian Red Sea beaches have never been studied before. All of quantitative studies in the Red 
Sea were dealt with the meiofauna in the Jordanian coast (Huling, 1975; Grelet et al., 1983 and 1987). Meiobenthic studies in the Egyptian Red Sea focused on taxonomy, particularly for harpacticoid copepods (Nicholls, 1944; Noodt, 1964; Por, 1967 \& 1979).

The current study aims to study the seasonal variations in the community structure and distribution strategies of meiobenthic organisms in the Northern Red Sea as well as the impact of the sediment characteristics and the hydrographic features of the selected sites on the meiobenthic communities.

\section{STUDY AREAS}

\section{MATERIALS AND METHODS}

All selected sites are located at the coast of Red Sea Governorate; which extends for almost $1080 \mathrm{Km}$ shoreline. In total, 12 sites were sampled; 10 inshore sites and 2 sites on the offshore islands of Abu-Menqar and Wadi El Gemal (Fig. 1).

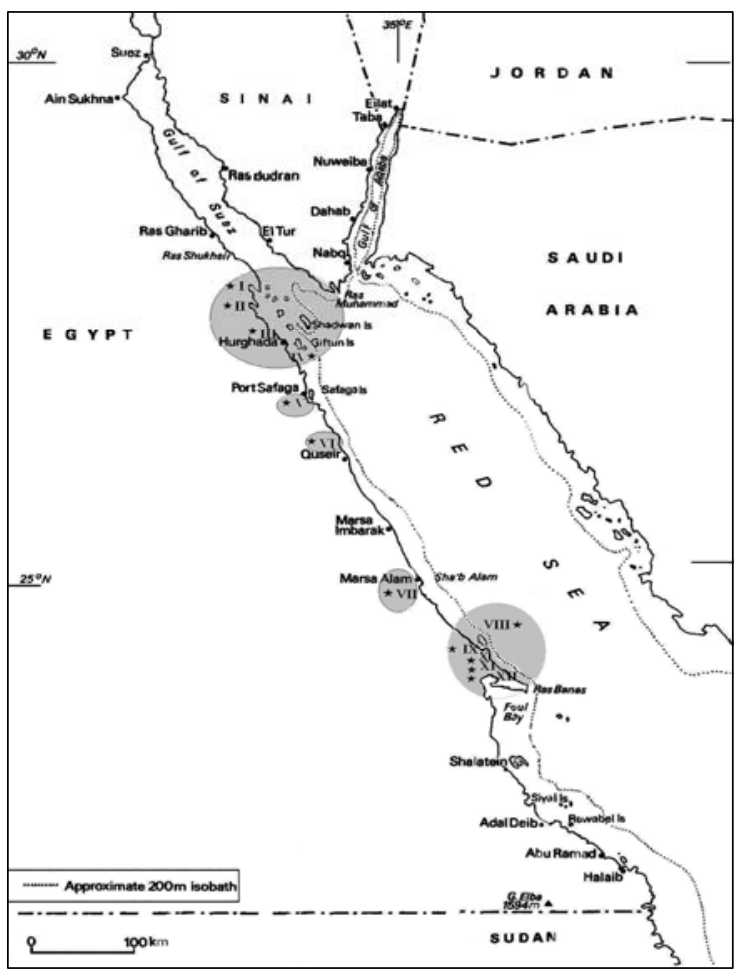

Fig. 1: Map of the northern Red Sea showing the sampling sites (I. Gabal El Zeit, II. Al Gemsha, III. Sama Beach, IV. Abo Menqar Island, V. Safaga, VI. Al Hamraween VII. Marsa Alam, VIII. Wadi El Gemal Island, IX. Sharm El Luli, X. Um El Abas, XI. Al Qulaan and XII Hamata) at which meiobenthic investigations have been conducted. 


\section{MEASUREMENTS OF PARAMETERS}

\section{Water Temperatures, the granulometric analysis and total organic matters} (TOMs)

Water temperature was measured by inserting a glass mercury thermometer $\left(110^{\circ} \mathrm{C}\right)$ graduated to $0.5^{\circ} \mathrm{C}$ into the surface layer of at each zone for 2 minutes. Sediment samples ( $100 \mathrm{~g}$ of sediments) were taken by hand metal corer at each zone per site for grain size analysis of sediments followed methods described in Folk (1974), the mean grain size and other granulometric statistics were calculated using Folk and Ward methods (Folk and Ward, 1957). TOMs for each site determined by combustion of $1 \mathrm{~g}$ of fine sediment $(\mathrm{Mz}=+2 \varphi)$ was dried at $60^{\circ} \mathrm{C}$ for approximately 12 hours. Organic matters were then assessed as the percentage weight loss in the samples after combustion at $500{ }^{\circ} \mathrm{C}$ for 24 Hours (Holme and McIntyre,1984).

\section{Meiofaunal analysis}

Meiofaunal samples were collected using hand made metal corer with an internal diameter of $3.6 \mathrm{~cm}$ and a total inner area of $10 \mathrm{~cm}^{2} .18$ samples per site were collected seasonally from spring 2006 to winter 2007. The sampling regime was designed to cover different littoral zones (Supralittoral, Eulittoral and Sublittoral zones). At each zone, 3 core samples were taken and the obtained sediment was divided immediately into two subsamples of $0-5 \mathrm{~cm}$ and $5-10 \mathrm{~cm}$. Samples were preserved in $4 \%$ neutralized formaldehyde solution with Rose Bengal stain $(0.5 \mathrm{~g} / \mathrm{l})$. In the laboratory, they were passed through two sieves; the top one with a mesh size of $500 \mu \mathrm{m}$ (captured the macrobenthos) while bottom one had a mesh size of $50 \mu \mathrm{m}$. Organisms retained on the lower sieve were considered as meiobenthos (Heip et al., 1979). All samples were counted under binocular stereomicroscope (Prior, S2000) at magnification of $10 \mathrm{X}$.

Identification of meiobenthic organisms were performed using the keys of Riedl (1969); Ben-Ellliahu (1972); Glynn (1972); Lerner-Seggev (1972); Por (1972); Tarjan (1980); Norenburg (1988); Platt and Warwick (1988) and Huys et al. (1996).

\section{Data analysis}

Multi-Ways analysis of variance was used to test the significance differences in abundances of meiobenthos between sites, seasons, zones and depths. The interactions between these factors were applied, using SYSTAT program (V.10.2.05, 2002). Diversity indices and cluster analyses (Bray-Curtis similarity) were carried out, using the PRIMER software package (PRIMER V.5.2, 2002).

\section{RESULTS \\ Water temperature and sediment characteristics of the study area}

Small variation in the seasonal water temperatures were observed in the study sites. The southern sites had slightly higher values than those recorded in the northern site (Table 1). The highest seasonal temperature was recorded in 
Wadi El Gemal Island $\left(25.6^{\circ} \mathrm{C} \pm 0.9\right)$, while the lowest was recorded in Gabal El Zeit with average water temperature value of $24.3^{\circ} \mathrm{C} \pm 1.13$. The maximum average temperature $\left(28.64^{\circ} \mathrm{C}\right)$ while the minimum was $21.32^{\circ} \mathrm{C}$ (Fig. 2).

Table 1: Water Temperature, sediment characteristics and type of shore according to the exposure to wave of the studied sites (2006-2007)

\begin{tabular}{|c|c|c|c|c|c|}
\hline Site Parameter & $\begin{array}{c}\text { Water } \\
\text { Temperature } \\
{ }^{\circ} \mathrm{C}\end{array}$ & TOMs (mg/g) & $\operatorname{Mz}(\varphi)$ & Sorting & $\begin{array}{l}\text { Exposure to } \\
\text { wave action }\end{array}$ \\
\hline & Mean \pm SD & Mean \pm SD & Mean \pm SD & & \\
\hline Gabal El-Zeit & $24.3 \pm 1.13$ & $5.8 \pm 0.4$ & $0.17 \pm 0.9$ & poorly sorted & protected \\
\hline Al-Gemsha & $24.4 \pm 0.9$ & $5.9 \pm 1.2$ & $0.03 \pm 0.6$ & $\begin{array}{c}\text { moderately } \\
\text { sorted }\end{array}$ & $\begin{array}{c}\text { Semi } \\
\text { protected }\end{array}$ \\
\hline Sama Beach & $24.9 \pm 1.07$ & $5.1 \pm 0.8$ & $0.07 \pm 0.6$ & poorly sorted & $\begin{array}{c}\text { Semi } \\
\text { protected }\end{array}$ \\
\hline Abo-Menqar Island & $24.5 \pm 1$ & $5.8 \pm 0.3$ & $-0.03 \pm 0.7$ & $\begin{array}{c}\text { moderately } \\
\text { sorted }\end{array}$ & exposed \\
\hline Safaga & $24.9 \pm 0.6$ & $6.0 \pm 1.2$ & $0.43 \pm 0.4$ & poorly sorted & protected \\
\hline Al-Hamraween & $24.9 \pm 0.85$ & $5.7 \pm 0.4$ & $-0.57 \pm 1$ & $\begin{array}{l}\text { moderately } \\
\text { sorted }\end{array}$ & exposed \\
\hline Marsa Alam & $25.1 \pm 1.1$ & $4.1 \pm 1$ & $-0.93 \pm 1.3$ & $\begin{array}{l}\text { moderately } \\
\text { well sorted }\end{array}$ & exposed \\
\hline Wadi El-Gemal Island & $25.6 \pm 0.93$ & $6 \pm 0.8$ & $-0.6 \pm 1.4$ & $\begin{array}{l}\text { moderately } \\
\text { sorted }\end{array}$ & $\begin{array}{c}\text { Semi } \\
\text { protected }\end{array}$ \\
\hline Um El-Abas & $25.3 \pm 0.9$ & $6 \pm 1.4$ & $0.37 \pm 0.2$ & $\begin{array}{l}\text { moderately } \\
\text { sorted }\end{array}$ & $\begin{array}{c}\text { Semi } \\
\text { protected }\end{array}$ \\
\hline Sharm El-Luli & $25.3 \pm 0.9$ & $5 \pm 1$ & $-1.1 \pm 1.2$ & poorly sorted & protected \\
\hline Al-Qulaan & $25.3 \pm 1$ & $7.5 \pm 1$ & $-0.97 \pm 0.5$ & poorly sorted & protected \\
\hline Hamata & $25.5 \pm 1.16$ & $6.4 \pm 0.5$ & $-0.53 \pm 0.4$ & $\begin{array}{c}\text { moderately } \\
\text { sorted }\end{array}$ & exposed \\
\hline
\end{tabular}

Legend: $\mathrm{SD}=$ Standard deviation and shadowed cells indicates the maximum values.

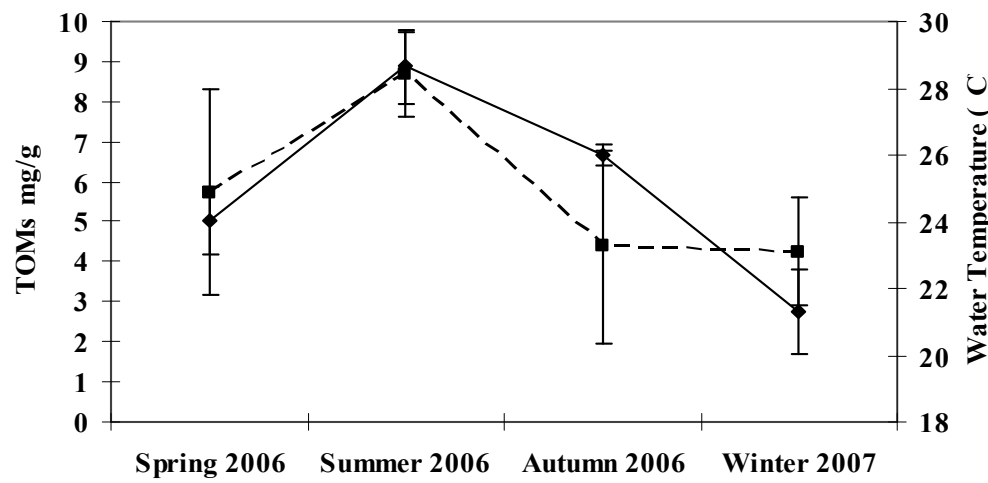

Season

Fig. 2: Seasonal variation in water temperature $\left({ }^{\circ} \mathrm{C}\right)$ and TOMs in the area of study.

* The dotted line represent TOMs values while the solid line represent water temperature values. 
TOMs, median grain size $(\mathrm{Mz})$ and sorting indices for all sites are listed in Table (1). The recorded variations in TOMs between sites were found to be limited. The highest value $(7.5 \pm 1 \mathrm{mg} / \mathrm{g})$ was recorded at Al Qulaan, while Marsa Alam had the lowest value $(4.1 \pm 1 \mathrm{mg} / \mathrm{g})$. On seasonal basis, TOMs increased in spring to reach the maximum in summer $(8.7 \pm 1.1 \mathrm{mg} / \mathrm{g})$, then decreased during the following seasons (Fig. 2).

At all sites, sediments exhibited coarsy nature. Sharm El Luli showed the coarser median grain size with an average median grain size of $-1.1 \pm 1.2$. In contrast, Safaga had a relatively fine value $(0.43 \pm 0.4)$. In general, sheltered sites exhibited poorly sorting of sediments. In contrast, the exposed sites to wave and current exhibited moderate sorted sediments (Table 1).

\section{Meiofaunal composition and abundance}

Free living Nematoda, harpacticoid copepoda, Polychaeta and Ostracoda represented the most important interstitial meiobenthic taxa, forming $93 \%$ of total meiobenthic count in the study area (Fig. 3). Oligochaeta, Gnathostomulida, Nemertea, Kinorhyncha, Cumacea, Isopoda and Amphipoda were recorded with extremely low densities (Appendix 1). Nematoda represented the most abundant group, contributing with $67 \%$ of total count. The species Ptycholaimellus ponticus, Theristus clax and Aulolalaimus oxycephalus showed higher densities among the overall represented nematode species. Harpacticoid copepods comprised 15 species and dominated by Canuella perplexa (formed $15.3 \%$ of total copepod counts). Polychaeta was represented by 25 species belonging to 14 families and were dominated by Exogone sp. (15 $\%$ of total polychaete count). Finally, Ostracoda was ranked fourth in term of abundance and was represented by 5 species. Among them; Xestoloberis sp. was the most abundant. Other groups accounted for $7 \%$ of total meiofaunal density.

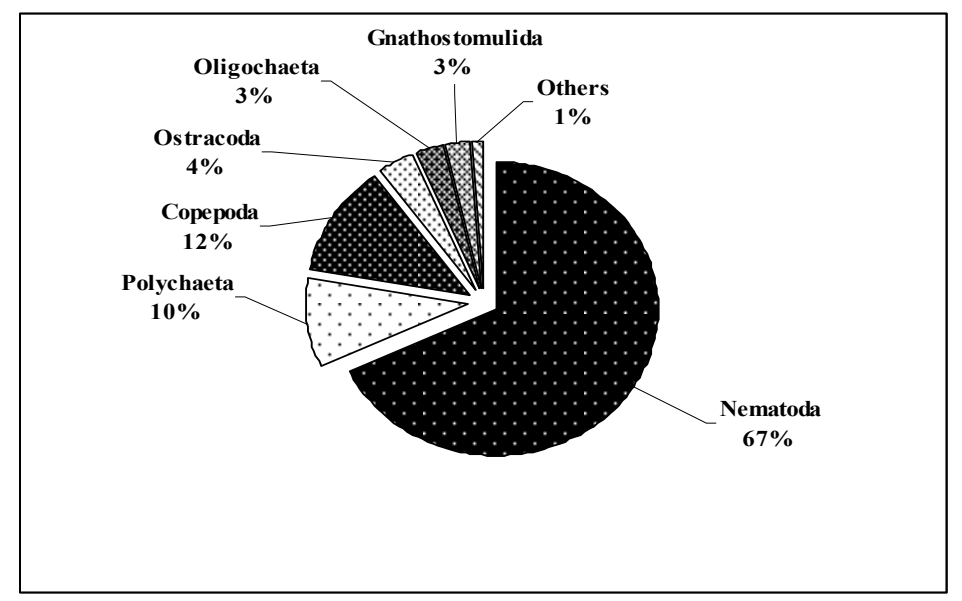

Fig. 3: Percentages of the different interstitial meiobenthic groups. 
Meiofaunal abundance was found to be influenced significantly by season, sites, littoral zones and sediment depths significantly $(P<0.001)$. All interactions between variables were significant (Table 2). The highest value of $166.1 \pm 91.4$ organisms $/ 10 \mathrm{~cm}^{2}$ was recorded at Safaga. In contrast, Gabal El Zeit showed the lowest density values with an overall mean of $38.2 \pm 22.2$ organisms $/ 10 \mathrm{~cm}^{2}$ (Fig.4).

Table 2: Multiple ANOVA performed on the effects of site, season, zone and depth on the meiofaunal abundance.

\begin{tabular}{lcc}
\hline Source of variation & F-ratio & P value \\
\hline Site & 62.205 & $0.000^{*}$ \\
Season & 25.546 & $0.000^{*}$ \\
Zone & 4.451 & $0.012^{*}$ \\
Depth & 121.791 & $0.000^{*}$ \\
Site*Season & 38.018 & $0.000^{*}$ \\
Site*Zone & 30.113 & $0.000^{*}$ \\
Site*Depth & 4.459 & $0.000^{*}$ \\
Season*Zone*Depth & 16.576 & $0.000^{*}$ \\
Season*Zone & 7.924 & $0.000^{*}$ \\
Season*Depth & 8.801 & $0.000^{*}$ \\
Zone*Depth & 10.045 & $0.000^{*}$ \\
Site*Season*Zone & 6.447 & $0.000^{*}$ \\
Site*Season*Depth & 6.258 & $0.000^{*}$ \\
Site*Zone*Depth & 3.867 & $0.001 *$ \\
Site*Season*Zone*Depth & 5.157 & $0.000^{*}$ \\
Error & & \\
\hline
\end{tabular}

*Indicates that this value was significant at level of 0.05 .

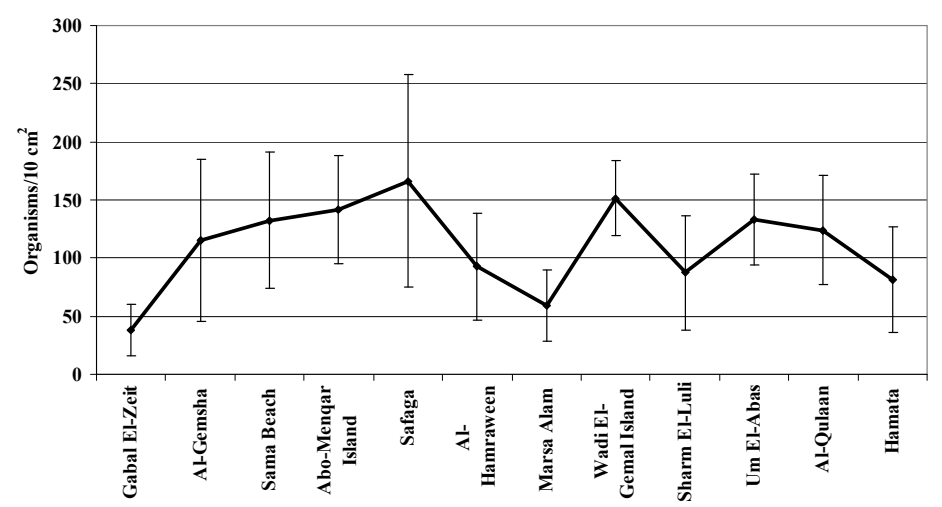

Fig. 4: Overall means of meiofaunal densities recorded at all studied sites

Meiofaunal densities peaked in summer with an overall mean value of $130.1 \pm 101.6$ organisms $/ 10 \mathrm{~cm}^{2}$, densities fluctuated between $100.5 \pm 84.6$ organisms $/ 10 \mathrm{~cm}^{2}$ (in autumn) and $107 \pm 110.7$ organisms $/ 10 \mathrm{~cm}^{2}$ (in winter). 
In warm seasons (spring, summer and autumn), the meiofaunal organisms inhibited the eulittoral zone more densely. In contrast, meiofauna inhibited the sublittoral zone more densely in winter. Regarding zone and season, the highest density of meiobenthos was recorded in the eulittoral zone in summer (average $151.3 \pm 101.9$ organisms $\left./ 10 \mathrm{~cm}^{2}\right)$, while the lowest was recorded in the sublittoral zone in autumn (average $79.9 \pm 67.4$ organisms $/ 10 \mathrm{~cm}^{2}$ ) (Fig. 5).

Generally, meiobenthos occupied the upper layers of sediment more densely than the lower layers at all seasons with an overall means value of 131 organisms $/ 10 \mathrm{~cm}^{2}$ and 85 organisms $/ 10 \mathrm{~cm}^{2}$ respectively. Regarding seasons and depths, the highest density of meiobenthos was recorded in the upper sediment layers in summer (average $153 \pm 107.2$ organisms $/ 10 \mathrm{~cm}^{2}$ ). In contrast, the lowest density was estimated in the lower layer of sediment in winter (average $73.7 \pm 56.1$ organisms $/ 10 \mathrm{~cm}^{2}$ ) (Fig. 6)

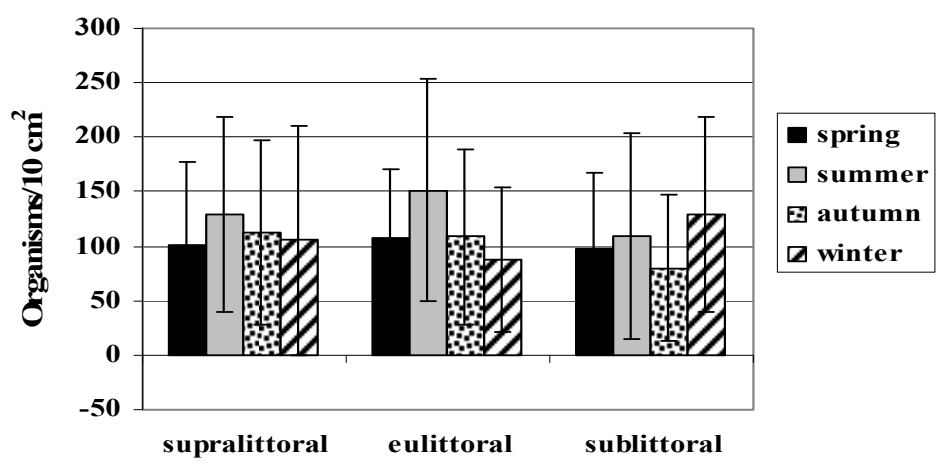

Fig. 5: Overall means of seasonal abundance of meiobenthos estimated in the different littoral zones.

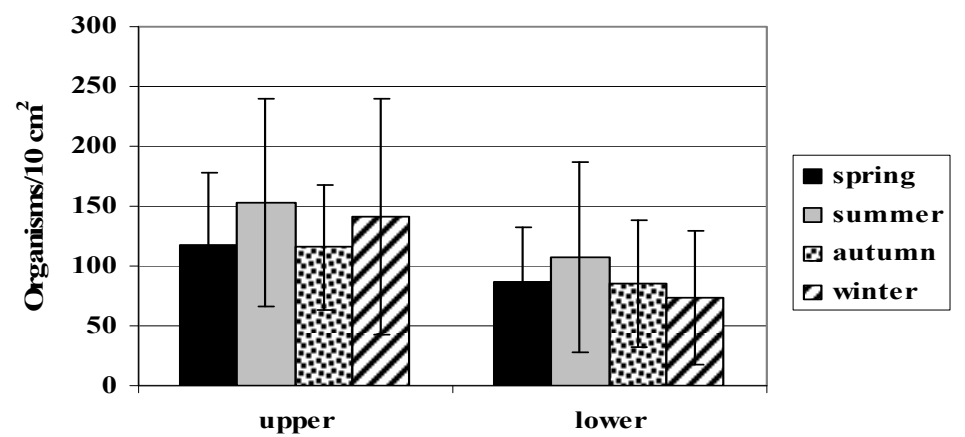

Fig. 6: Seasonal averages of meiobenthos in the upper $(0-5 \mathrm{~cm})$ and lower $(5-10 \mathrm{~cm})$ sediment layers. 
It is noticed that meiofauna was estimated irregularly and patchly at all sites, especially at Al Gemsah and Gabal El Zeit. However, organisms were evenly distributed in Wadi El Gemal Island and Um El Abas sites.

\section{Diversity of meiobenthic assemblages}

Overall 141 of interstitial species belonging to 125 genera were identified belonging to 6 phyla, 8 classes; each phylum was represented by only one class except nematodes and annelids, where each was represented by two classes, namely Adenophorea and Secernentea for Nematoda and, Oligochaeta and Polychaeta respectively. Crustacea was represented only by class Maxillopoda, included orders, Harpacticoida, Ostracoda, Amphipoda, Isopoda and Cumacea (Table 3).

Meiobenthic communities showed an obvious variation among the investigated sites. Spatially, Al Qulaan site attained the highest number of species (31 species). In contrast, Marsa Alam site was attained the lowest value (11 species) (Table 3$)$.

Table 3: Diversity of meiobenthos in the area of study (2006-2007).

\begin{tabular}{lccccc}
\hline \multicolumn{1}{c}{ taxa } & Chylum & Order & Family & Genera & species \\
\hline Nematoda & 2 & 5 & 32 & 61 & 85 \\
Crustacea & 1 & 5 & 21 & 28 & 28 \\
Annelida & 2 & 5 & 12 & 22 & 24 \\
Gnathostomulida & 1 & 2 & 2 & 2 & 2 \\
Nemertina & 1 & 1 & 1 & 1 & 1 \\
Kinorhyncha & 1 & 1 & 1 & 1 & 1 \\
Total & $\mathbf{8}$ & $\mathbf{1 9}$ & $\mathbf{6 9}$ & $\mathbf{1 2 5}$ & $\mathbf{1 4 1}$ \\
\hline
\end{tabular}

High values of species eveness estimated for different sites $(>0.8)$ indicated the lack of strong dominance among any meiobenthic populations. The highest species eveness value was calculated for Sharm El Luli site $(E=0.94)$ while the lowest value of 0.81 was calculated to Marsa Alam site $(\mathrm{E}=0.81)$ (Table 4). The highest values for Shannon-Winner index $(H)$ and species richness index (D), the highest values were estimated for Sharm El Luli being 3.07 and 5 respectively. In comparisons, Safaga displayed the lowest value of species richness being 3.3 (Table 4).

The cluster analysis for the common meiobenthic species recorded at the different sites (Fig. 7), showing one main cluster included 6 sites representing 3 subclusters. The first was formed by Sharm El Luli and Al Qulaan sites (69.3\%), while Abu Menqar Island and Um El Abas site constituted the second subcluster with a similarity value of $66.9 \%$. The third subcluster was formed by Wadi El Gemal Island and Sama Beach sites (64.2\%). 
Table 4: Average value for each of total number of species (S), Eveness (E) and Shannon-Weaver Index (H) and species richness (D) of meiobenthic organisms for all sites in the area of study (2006-2007).

\begin{tabular}{lcccc}
\multicolumn{1}{c}{ Site } & S & E & H & D \\
\hline I. Gabal El Zeit & 13 & 0.91 & 2.53 & 3.6 \\
II. Al Gemsha & 19 & 0.84 & 2.55 & 3.5 \\
III. Sama Beach & 23 & 0.9 & 2.94 & 4.3 \\
IV. Abu Menqar Island & 23 & 0.93 & 2.9 & 3.9 \\
V. Safaga & 17 & 0.84 & 2.63 & 3.6 \\
VI. Al Hamraween & 20 & 0.84 & 2.7 & 4.1 \\
VII. Marsa Alam & 11 & 0.81 & 2.35 & 3.3 \\
VIII. Wadi El Gemal Island & 23 & 0.9 & 2.83 & 3.9 \\
IX. Sharm El Luli & 26 & 0.94 & 3.07 & 4.5 \\
X. Um El Abas & 26 & 0.9 & 3.07 & 5 \\
XI. Al Qulaan & 31 & 0.92 & 2.86 & 4 \\
XII. Hamata & 14 & 0.82 & 2.5 & 4.1 \\
\hline
\end{tabular}

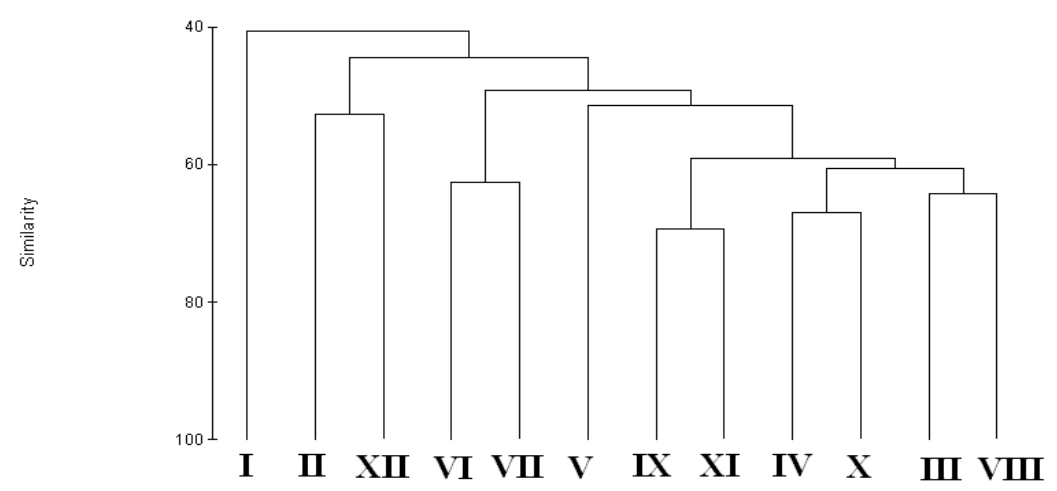

Fig. 7: Dendrogram of the cluster analysis of meiobenthic communities at the studied sites where; I. Gabal El Zeit, II. Al Gemsha, III. Sama Beach, IV. Abo Menqar Island, V. Safaga, VI. Al Hamraween VII. Marsa Alam, VIII. Wadi El Gemal Island, IX. Sharm El Luli, X. Um El Abas, XI. Al Qulaan and XII Hamata.

\section{DISCUSSION}

In the present study, densities of meiobenthos were very close to that recorded by Hulings (1971) in sandy beaches along the coast of Jordan. Sheltered sites namely; Al Gemsha, Safaga, Wadi El Gemal Island, Sharm El Luli and Al Qulaan were observed to harbor higher densities of meiobenthic organisms rather than those were found in exposed sites (Marsa Alam and Al 
Hamraween). This is in agreement with studies concerned with the effect of agitation on the meiobenthic abundance (Giere, 2009).

Grain size plays a dominant role in meiofaunal distribution and can serve as the integrative key factors that characterize the habitat of these organisms. (Giere, 2009). The highest abundance of meiofauna was recorded in the sites that attained higher content of silt and clay (Safaga). Sites which attained lower of fine sediment had lower abundance of inhabited meiobenthic organisms (i.e. Abo Tartoor).

TOMs was observed to be of significant influence on the meiofaunal abundance of the investigated sites. Sites with high TOMs attained high densities of meiobenthos overall investigated sites (Al Gemsha, Safaga and Al Qulaan). Tietgen, (1980) and Warwick (1989) stated that the content of organic matter has a significant influence on the distribution of meiofauna. Along the coasts of South Africa, meiofauna abundance was positively correlated with detritus content of sediment (McLachlan et al., 1981).

Horizontally, meiofauna are known to exhibit a patchy distribution in sediments that appear to be homogeneous (Heip and Engless, 1977). The meiobenthic abundance of the selected sites appeared patchy in term of their distribution. True causes of the patchiness phenomenon are not known but several ideas have been discussed. Gerlach (1977) suggested that the random placement of a macrofaunal carcass (dead fish, dead crab) and its subsequent leaking of organic matter may attract meiofauna and that the patches may thus be the result of attraction to an organic point source. Others suggested that the foods of meiofauna (bacteria and microflora) are patchily distributed and that certain attractive food sources, being so localized, can then determine the horizontal distribution of the meiofauna. (Lee et al., 1977). Selective predation on meiofauna could also cause patchy distribution. Meiofaunal predators might remove particular taxa (or size classes), this localized removal could then result in a discordant distribution (Levin and Paine, 1974).

In the current study, meiobenthic organisms inhibited the sublittoral zones with relatively denser values than other zones. This might be due to the relatively fine median grain size occurring in this zone compared to other littoral zones. Similar findings were reported by Schmidt and Westheide (1969) who studied the macrofauna and meiofauna of tidal beaches on the Island of Sylt in the North Sea and stated that densities of meiofauna diminished from low water mark (sublittoral) towards the high water mark (supralittoral).

In the present study, significant differences in meiofaunal densities were noticed between the different sediment layers, meiobenthos were inhabited the upper layer densely. Total of $62 \%$ of meiobenthos organisms were found at the upper layer $0-5 \mathrm{~cm}$. Giere (2009) reported that in a vertical sediment profile, the upper few centimeters usually harbor more meiofauna than the deeper horizons. This relates to the richer supply with oxygen and food particles (Yingest, 1978). 
The meiobenthic assemblage in the area of study is well diversified and dominated by nematodes, harpacticoid copepods, polychaetes and ostracodes. Similar results were observed by many studies (Hulings, 1975; Sivaleela, 2009; Semprucci, 2010). Sites with moderately well sorted sediment were inhabited by relatively high number of meiobenthic species (Al Gemsha, Abo Menqar, Wadi El Gemal Island and Al Qulaan) than those with poorly sorted sediments (Safaga and Hamata). Giere (2009) reported that moderately well sorted medium sand harbored the most diverse meiofauna. He explained that species numbers remained relatively high but population density may decrease in coarse sandy beaches.

Results of this study confirmed the presence of distinct difference in overall community structure between sites. Community structures of sandy shores were characterized by lower densities and the higher evenness compared to other shore types. This is due to the fact that the numerical dominance is shared between the represented species at each site which leads to higher species diversity. Similary, Lie (1968) found high species diversity in coarse sediment at Pauget Sound off the coast of Washington.

Dexter (1980 \& 1989) stated that Red Sea beaches are characterized by higher diversity indices than those estimated for the benthic animals of the intertidal beaches of the Mediterranean Sea. In the current study, Al Qulaan site was found to be the most diversified site and rich in meiofaunal communities. This is mainly related to several reasons including; the location of site within Wadi El Gemal Protected Area which contains the most productive habitats, namely; mangrove, seagrass and large beds of seaweed beds, therefore, more availability of food for the meiobenthos as well a the lack of significant negative human impact. Gibbons (1991) stated that the healthiness of the meiofaunal community might be related to its location in areas being away enough from any human impact of any sort, which might significantly enhance the species richness of meiofaunal communities

Meiofauna varied seasonally, with highest abundance in summer and the lowest in autumn. Fishar (2000) studied the monthly fluctuation of the meiofauna of Lake Qarun and reported considerable monthly fluctuations in abundance and biomass of meiofauna over the year with sudden decline in autumn due to strong wind. Such detrimental effects of wind on meiobenthos have been reported by several workers on the Indian coast (Reddy and Hariharan, 1985; Kondalaroio and Murty, 1988; Ansari and Parulekar, 1993). Rudnick et al. (1985) stated that meiofauna and macrofauna varied seasonally in Narragansett Bay, with the highest abundances in late spring and lowest in late summer and autumn. They suggested that spring time increases were attributable to excess food resources and that the timing of the increase was triggered by a rapid rise in temperature. 


\section{AKNOWLEDGMENTS}

Deep thanks are expressed to all members of the Red Sea protectorates at Hurghada, Marsa Alam and Wadi El Gemal areas. Sampling could have not been completed without their help, we are really very grateful.

\section{REFERENCES}

Alongi, D. M. (1990). Community dynamics of the free living nematodes in some tropical mangrove and sand flat habitats. Bull. Mar. Sci., 46: 358373.

Ansari, Z. A. and Parulekar, A. H. (1993). Distribution, abundance and ecology of the meiofauna in a tropical estuary along the west coast. Hydrobiology, 262: 115-126.

Armonies, W. and Reise, K. (2000). Faunal diversity across sandy shore. Mar. Ecol. Prog. Ser. 196: 49-57.

Ben-Ellliahu, M. N. (1972). Polychaetes errantia of the Suez Canal. Isr. J. Zool., 21: 189-237.

Coull, B. C. (1990). Are members of the meiofauna food for higher trophic levels? Trans. Am. Microsc. Soc., 109: 233-246.

Dexter, D. M. (1981). Intertidal fauna Israeli and Sinai Sandy beaches of the Mediterranean and Red Sea. Bull. Mar. Sci., 31: 8-12.

Dexter, D. M. (1989). The sandy beach fauna of Egypt. Estuarine, Coastal and Shelf Science, 29: 261-271.

Fishar, M. R. (2000). Composition, Distribution and abundance of the meiobenthic fauna in Lake Qarun (Faiyoum, Egypt). Egypt. J. Aquat. Biol. \& Fish., 4 (3): 54-60.

Folk, R. L. and Ward, W. C. (1957). Brazos River bar: a study in significance of grain-size parameters, Sedimentology, 6: 73-93.

Gerlach, S. A. (1977). Attraction to decaying organisms as a possible cause for patchy distribution of nematodes in Bermuda beach. Ophelia, 16: 151-165.

Gibbons, M. J. (1991). Rocky shore meiofauna: a brief overview. Transactions of the Royal Society of South Africa. 47: 595-603. 
Giere, O. (2009). Meiobenthology: The microscopic fauna in aquatic sediments. Springer-Verlag. Berlin.

Glynn. P. W. (1972). Isopoda of the Suez Canal .Isr. J. of Zool., 21: 275-300.

Hicks, G. R. (1984). Spatio-temporal dynamics of meiobenthic copepod and impact of predation-disturbance. J. Exp. Mar. Biol. Ecol., 81: 47-72.

Holme, N. A. and McIntyre. A. D. (Eds.). (1984). Methods for the study of marine benthos, $2^{\text {nd }}$ edition Blackwell Oxford, $387 \mathrm{pp}$.

Hulings, N. C. (1975). Spatial and quantitative distribution of sand beach meiofauna in the Northern Gulf of Aqaba. Rapp. COMM. Int. Mer. Medit., 23: 163-181.

Huys, R.; Gee, J.M.; Moore, C.G. and Hamond, R. (1996) Marine and brackish water Harpacticoid copepods. Part 1. (Synopses of the British Fauna No.51) (Eds. Barnes, R. S. K. and Crothers, J. H.) Field Studies Council, Shrewsbury. 352 pp.

Japan International Cooperation Agency, JICA (1999). The study on tourism development projects in the Arab Republic of Egypt: main report. Cairo: Egyptian Tourism Development Authority.

Jones, D. A.; Ghamrawy M.; and.Wahbeh. M. I. (1987). Littoral and shallow subtidal environments .In. Red Sea Key Environ ments .Edt..Edwards, A. J. and Head, S. H., lst edition.pergamon press, 441 pp.

Kondalarao, B. and Murty, R. (1988). Ecology of intertidal Meiofauna of Kakinada Bay, East coast of India. Indian J. Mar. Sci., 17: 40-47.

Lee, W. Y.; Morris, A. and Boatwright, D. (1980). Mexican oil spill: a toxicity study of oil accommodated in seawater on marine invertebrates. Mar. Pollut. Bull., 11: 231-234.

Lerner-Seggev R..(1972). Ostracoda of the Suez Canal. Isr. J. of Zool. 21: 239249.

Levin, S. A. and Paine. R. T. (1974). Disturbance, patch formation, and community structure. Proceedings of the National Academy of Sciences (USA) 71: 2744-2747. 
Lie, U. (1968). A quantitative study of benthic fauna in Puget Sound, Washnigton, U. S. A., IN (1963-1964). Frikeridir, Skr. Ser. Havunders, 14(5): 229-256.

McLachlan, A.; Wooldridge, T. and Dye, A. H. (1981). S. Afr. Tydskr. Dierk., 16: 219-231.

Nicholls, A. G. (1944). Littoral Copepoda from the Red Sea. Ann. Mag. Nat. Hist., 11: 487-503.

Nicolaidou, A.; Bourgoutzani, F.; Zenetos, A.; Guelorgen, O. and Perthuisot, J. P. (1988). Distribution of mollusks and polychaetes in coastal lagoon in Greece. Estuarine Coastal and Shelf Science, 26: 373-378.

Nodot, C. (1982). Reproduction et croissance des copepods harpacticoids psammiques Halctinosoma herdmani (T \& A Scott) et Tryphoema Porca Monard. Tethys, 10: 373-378.

Noodt, W. (1964). Copepoda Harpacticoida aus dem Littoral des Roten Meeres. Kieler Meeresforsch., 20: 128-154.

Norenburg, J. L. (1988). Remarks on marine interstitial nemertines and key to the species. Hydrobiologia. 156: 87-92.

Platt, H. (1981). Meiofaunal dynamic and the origin of the metazoan. In: Greenwood P. H. (ed.). The evolving biosphere. Cambridge University Press, Cambridge, pp 207-216.

Platt, H. M. and Warwick, R. M. (1983) Free living marine nematodes. Part I. British Enoplids. Synopses of the British Fauna No.28 (Eds. Kermack, D.M. and Barnes, R.S.K.) Cambridge University Press, Cambridge.307 pp.

Platt, H. M. and Warwick, R. M. (1988) Free living marine nematodes. Part II. British Chromadorids. Synopses of the British Fauna No.38 (Eds. Kermack, D.M. and Barnes, R. S. K.) E. J. Brill/Dr Backhuys, Leiden. 502 pp.

Por. F. D. (1972). Copepoda harpacticoida of the Suez Canal .Isr. J. of Zool. 21: 249-264.

Reddy, H. R. and Hariharan, V. (1985). Meiobenthos of Netravathi-Gurpur Estuary, Bangalore. Indian J. Mar. Sci., 14: 163-164. 
Riedl, R. J. (1969). Gnathostomulid from America. Sci., 163: 445-42.

Riser, N. W. (1984). General observations on the intertidal interstitial fauna of New Zealand. Tane, 30: 239-250.

Rudnick, D.T.; Elmgren R. and Frithsen. J. B. (1985). Meiofaunal prominence and benthic seasonality in a coastal marine ecosystem . Oecalogia. (Berlin) (1985) 67: 157-168.

Semprucci, F; Colantoni, P; Bladelli, G; Rocchi, M and Balsamo, M. (2010). The distribution of meiofauna on back-reef sandy platforms in the Maldives (Indian Ocean). Mar. Ecolo., pp 1-16.

Shaalan, I. M. (2005). Sustainable tourism development in the Red Sea of Egypt threats and opportunities. Journal of Cleaner Production, 13: 83-87.

Shaw, M. and Jenkins, G. P. (1992). Spatial variation in feeding, prey distribujtion and food limitation of juvenile flounder Rhombsolea tapirina (Guntheri). J. Exp. Mar. Biol. Ecol., 163: 1-21.

Sivaleela, G. (2009). Meiofauna of Tamil Nadu coast with special reference to marine free-living nematodes. Ph. D. University of Madras. India. 197 pp.

Tarjan, A. C. (1980). Illustrated guide to the marine nematodes. IFAS, Univ. of Florida, Gainesville. 135 pp.

Warwick, R. M. (1989). The role of meiofauna in the marine ecosystem: evolutionary considerations. Zool. J. Linn. Soc., pp 229-241.

Westheide, W. (1991). The meiofauna of the Galapagos. A review. In: James M. J. (ed) Galapagos Marine Invertebrates. Taxonomy, biogeography, and evolution in Darwin's Islands. Plenum Press, New York, London, pp 3773.

Yingest, J. Y. (1978). Patterns of micro-and meiofaunal abundance in marine sediments, measured with adenosine tri-phosphate assay. Mar. Biolo., 47: 41-54. 


\section{Appendix 1: List of recorded species in the present study}

Phylum: Nematoda

Enoplus sp.

Enoplolaimus longicaudatus Southern, 1914

Enoplolaimus subterraneus Gerlach, 1952

Enoplolaimus littoralis Schulz, 1936

Enoploides brunettii Gerlach, 1953

Anoplostoma viviparum Bastian, 1865

Phanoderma albidium Bastian, 1865

Crenopharynx marioni (Southern, 1914)

Dolicholaimus marrioni De Man, 1888

Trissonchulus obtusus Bresslau and Stekhoven, 1935

Syringolaimus filicaudatus Vitiello, 1970

Syringolaimus smarigdus Cobb, 1923

Syringolaimus striatocaudatus De Man, 1888

Thoracostoma microlobatum Allgen, 1947

Oxystomina elongate (Butschli, 1874)

Halalaimus gracilis De Man, 1888

Halalaimus isaitshikovi (Filipjev, 1927)

Halalaimus longicaudatus Filipjev, 1927

Metoncholaimus scanicus (Allgen, 1935)

Metoncholaimus intermedius

Oncholaimus attenuatus Dujardin, 1845

Oncholaimus bachycercus De Man, 188

Oncholaimus oxyuris Ditelevsen, 1911

Oncholaimus campylocercoides De Coninck and Stekhoven, 1933

Viscosia abyssorum (Allgen, 1933)

Viscosia cobbi Filipjev, 1918

Viscosia elegans (Kreis, 1924)

Viscosia glabra (Bastian, 1865)

Viscosia viscosia (Bastian, 1865)

Pontonema vulgare (Bastian, 1865)

Eurystomina sp.

Pareurystomina sp.

Cryptonchus abnormis Algen, 1933

Onchulus longicauda Daday, 1899

Tobrilia imberbis Andrassy, 1953

Tobrilus sp.

Tripyla sp.

Bathylaimus arthropappus Wieser and Hopper, 1967

Tripyloides gracilis (Ditlevsen, 1918)

Tripyloides marinus (Butschli, 1878)

Rhabdodemania major (Southern, 1914)

Rhabdodemania minor (Southern, 1914)

Chromadorina laeta De Man, 1876

Euchromadora gaulica Inglis, 1962

Neochromadora poecilosoma (De Man, 1893)

Ptycholaimellus ponticus (Filipjev, 1922)

Laimella vera Vitiello, 1971

Sabatieria pulchra (Schneider, 1906)

Filitonchus ewensis Platt, 1982

Esola longicauda Edwards, 1891

Euterpina sp.

Tisbe sp.

Porcellidium sp.

Order: Ostracoda

Loxoconcha ghardaqensis, Hartmann 1964.

Roundstonia macchesneyi Brady and Crosskey, 1871

Xestoleberis sp.

Cyprideis sp.

Sarsicytheridea $\mathrm{sp}$.

Order: Isopoda

Microcerberus sp.

Angelliera sp.

Order: Cumacea

Cumella sp.

Cumopsis longipes Dohm, 1869

Order: Amphipoda

Ampelisca sp.

Grandidierella sp.

Monoculodes sp.

Urothoe sp.

Phylum: Annelida

Class: Oligocheata

Aktedrilus sp.

Clitellio sp.

Grania sp.

Class: Polychaeta

Autolytus sp.

Brania sp.
Cyatholaimus prinzi (Marion, 1870)

Marylynnia sp.

Paracyatholaimus sp.

Cheironchus sp.

Gammanema sp

Halichoanolaimus dolichurus Ssaweljev, 1912

Halichoanolaimus minor Ssaweljev, 1912

Halichoanolaimus robustus (Bastian, 1865)

Catanema macintyrei Platt and Zhang, 1982

Chromaspirina sp.

Spirina schneideri.(Villot, 1875)

Epsilonema sp.

Draconema sp.

Dracogalerus sp.

Aponema torosa (Lorenzen, 1973)

Monoposthia anonoposthia

Monoposthia costata (Bastian, 1865)

Haliplectus sp.

Ceramonema sp.

Ceramonema yunfengi Platt and Zhang, 1982

Dasynemoides albaensis (Warwick and Platt, 1973)

Desmoscolex sp.

Quadricoma sp.

Retrotheristus sp.

Theristus longus Platt, 1973

Theristus sp.

Xyala sp.

Xyala riemann Boucher and Helleauet, 1977

Sphaerolaimus maeoticus Filipjev, 1918

Sphaerolaimus macrocirculus Filipjev, 1918

Terschellingia sp.

Axonolaimus sp.

Aulolaimus oxycephalus De Man, 1988

Class: Secernentea

Rhabditis marina Bastian, 1865

Phylum: Crustacea

Class: Maxilopoda

Sub-class: Copepoda

Order: Harpacticoida

Longipedia weberi Scott, 1909

Cletodes sp. Brady, 1872

Canuella perplexa T \& A. Scott, 1893

Ameira sp. Boeck, 1865

Nitokra sp. Boeck, 1865

Ectinosoma sp. Boeck, 1865

Arenosetella sp. Wilson, 193

Stenhelia sp. Boeck, 1865

Typhlamphiascus sp. Lang, 1944

Harpcticus littoralis Sars, 1911

Laophonte inornata Scott, 1902

Exogone sp.

Phyllodocida sp.

Sphaerosyllus capensis Hartmann-Schroder, 1960 Typosyllis sp.

Hesione splendida Savigny, 1818

Glycera convolatus Keferstein, 1962

Glycera tesselata Grube, 1850

Armandia maculate Webster, 1884

Polyphthalmus sp.

Capitella capitata Fabricius, 1780

Capitilla giardi Mensnil, 1897

Ophryotrocha sp.

Pisionidens sp.

Caulleriella sp. Chamberlin, 1919

Cirratulus cirratus Muller, 1776

Dodecaceria sp.

Prionospio sp.

Magelona sp.

Rhaphidrilus sp.

Protodrilus brevis Jouin, 1970

Phylum: Gnathostomulida

Gnathostomula sp.

Haplognathia sp.

Phylum: Nemertea

Ototyphlonemertes sp.

Phylum: Kinorhyncha

Zelinkaderes klepali Nebelscick, 1995 